\title{
Meningkatkan Hasil Belajar Siswa dengan Metode Learning Comunity
}

\author{
Putu Eka Juliana Jaya \\ SMP Negeri 1 Denpasar \\ Denpasar, Indonesia \\ e-mail: wawarjaya@yahoo.com
}

Pengutipan: Jaya, P.E.J. (2020).

Meningkatkan Hasil Belajar Siswa dengan Metode Learning Community. Jurnal Pendidikan Ekonomi Undiksha, 12 (1), 36-49

\begin{abstract}
Riwayat Artikel Tanggal diajukan: 31 Mei 2020

Tanggal diterima : 7 Juni 2020

Tanggal dipublikasikan 29 Juni 2020

Abstrak

Penelitian ini bertujuan untuk mengetahui penerapan metode pembelajaran learning community untuk meningkatkan hasil belajar siswa pada mata pelajaran IPS di SMP negeri 1 Denpasar. Subjek penelitian adalah 48 orang siswa kelas VIII F. Data yang digunakan dalam penelitian ini adalah data primer dan data sekunder. Sumber data primer adalah siswa kelas VIII C SMP Negeri 1 Denpasar, tahun pelajaran 2018/2019. Prosedur penelitian dilaksanakan dengan menerapkan pendekatan community learning, yang terdiri dari 2 siklus: perencanaan, tindakan dan refleksi, pengamatan. Teknik pengumpulan data menggunakan teknik observasi, evaluasi tertulis, dan dokumentasi. Hasil penelitian menunjukkan bahwa: kegiatan dalam penelitian tindakan kelas ini dikatakan berhasil, dimana terjadi peningkatan aktivitas belajar dari total 45 siswa yang terdiri dari 25 siswa laki-laki dan 20 siswa perempuan, yang pada kondisi awal ada 19 siswa atau 42,22 persen tuntas, kemudian meningkat menjadi 36 siswa atau 80 persen pada siklus pertama dan akhirnya pada siklus kedua menjadi 45 siswa atau 100 persen. Terjadi peningkatan pada siklus pertama menjadi 36 siswa atau 80 persen dengan nilai rata-rata sebesar 78,89 dan siklus kedua meningkat menjadi 87,78 pada nilai ratarata dengan ketuntasan sebesar 100 persen.
\end{abstract}

Kata kunci: learning community; aktivitas; hasil belajar

\begin{abstract}
This study aims to analyze the implementation of community learning method to improve student learning outcomes in social science subjects at SMP Negeri 1 Denpasar. The research subjects were 48 students of class VIII F. The data used in this study were primary data and secondary data. The primary data source is class VIII C State 1st SMP Denpasar, school year 2018/2019. The research procedure was carried out by applying the community learning approach, which consisted of 2 cycles: planning, action and reflection, observation. Data collection techniques use observation, written evaluation, and documentation techniques. The results showed that: activities in classroom action research were said to be successful, where there was an increase in learning activities from a total of 45 students consisting of 25 male students and 20 female students, in the initial conditions there were 19 students or 42.22 percent complete, then increased to 36 students or 80 percent in the first cycle and finally in the second cycle to 45 students or 100 percent. There was an increase in the first cycle to 36 students or 80 percent with an average value of 78.89 and the second cycle increased to 87.78 at an average value with completeness of 100 percent.
\end{abstract}

Keywords : learning community; activities; learning outcomes 


\section{PENDAHULUAN}

Secara praktis, guru adalah ujung tombak dalam pembelajaran. Strategi dan manajemen guru untuk mengatasi masalah pembelajaran sangat dibutuhkan dalam upaya meningkatkan kualitas pembelajaran. Pelaksanaan pembelajaran di dalam kelas merupakan salah satu tugas utama guru, dan pembelajaran dapat diartikan sebagai kegiatan yang ditujukan untuk membelajarkan siswa. Dalam proses pembelajaran masih sering ditemui adanya kecenderungan meminimalkan keterlibatan siswa. Dominasi guru dalam proses pembelajaran menyebabkan kecenderungan siswa lebih bersifat pasif sehingga mereka lebih banyak menunggu sajian guru dari pada mencari dan menemukan sendiri pengetahuan, ketrampilan atau sikap yang mereka butuhkan (Purnamawati, Musmini, \& Werastuti, 2011).

Dalam implementasi materi, menemukan bahwa pembelajaran IPS lebih menekankan aspek pengetahuan, berpusat pada guru, mengarahkan bahan berupa informasi yang tidak mengembangkan berpikir nilai serta hanya membentuk budaya menghafal dan bukan berpikir kritis. Dalam pelaksanaan menilai pembelajaran IPS sangat menjemukan karena penyajiannya bersifat monoton dan ekspositoris sehingga siswa kurang antusias dan mengakibatkan pelajaran kurang menarik padahal guru IPS wajib berusaha secara optimum merebut minat siswa karena minat merupakan modal utama untuk keberhasilan pembelajaran IPS. permasalahan tersebut dapat dilihat dari hasil ulangan harian IPS yang pertama (pra siklus) di kelas VIII C SMP Negeri 1 Denpasar pada kompetensi dasar mendeskripsikan dan menjelaskan pengertian konflik, menganalisis faktor penyebab konflik, membedakan bentukbentuk konflik, mendiskripsikan dampak konflik, mengidentifikasi cara pengendalian konflik rata-rata 69,33 dan hanya 42,22 persen siswa mencapai nilai 70 atau lebih besar dari 70 . Padahal idealnya minimal harus mencapai 100 persen siswa mendapat 70 atau di atas 70 . Kondisi tersebut disebabkan oleh kenyataan sehari- hari yang menunjukkan bahwa siswa kelihatannya jenuh mengikuti pelajaran IPS. Pembelajaran sehari-hari menggunakan metode ceramah dan latihan soal secara individual dan tidak ada interaksi antar siswa yang pandai, sedang dan normal. Hal ini terbukti sebagian besar siswa mengeluh apabila diajak belajar IPS.

Kenyataan tersebut, menunjukkan bahwa proses yang dilakukan oleh guru untuk pembelajaran IPS belum aktif. Dengan demikian dapat diduga bahwa yang menjadi kendala yang dirasakan adalah masalah proses pembelajaran yang kurang variasi dan kurang melibatkan siswa secara aktif. Guru menggunakan model pembelajaran yang terkesan monoton sehingga siswa menjadi kurang aktif. Setelah memperhatikan situasi kelas yang seperti itu, maka perlu dipikirkan cara penyajian dan suasana pembelajaran IPS yang cocok untuk siswa, sehingga siswa dapat berpartisipasi aktif dalam proses pembelajaran. Saat ini pemerintah sudah sering mensosialisasikan berbagai model pembelajaran. Salah satu model pembelajaran yang disosialisasikan adalah model pembelajaran learning community. Learning community dilandasi oleh konstruktivisme sosial. Kontruktivisme sosial merupakan paradigma pembelajaran yang digagas oleh Vygotsky, pembelajaran berfokus pada proses dan interaksi dalam konteks sosial. Interaksi dan proses sosial mejadi perhatian dalam mencapai tujuan pembelajaran. Learning community merupakan suatu konsep terciptanya masyarakat belajar di sekolah, yakni proses belajar membelajarkan antara guru dengan guru, guru dengan siswa, siswa dengan siswa, dan bahkan antara masyarakat sekolah dengan masyarakat di luar sekolah, agar prestasi belajar siswa dapat ditingkatkan. Learning community berusaha menggeser pembelajaran yang bersifat individual menjadi pembelajaran yang bersifat sosial. Ini berarti iklim kompetitif dalam kelas harus diubah menjadi iklim sosial, sehingga tidak terjadi kesenjangan intelektual dan pengalaman di antara siswa.

Berdasarkan latar belakang di atas maka dapat dirumuskan masalah penelitian apakah pendekatan pembelajaran learning 
community dapat meningkatkan prestasi belajar IPS di kelas VIII C SMP Negeri 1 Denpasar tahun pelajaran 2018/2019?. Penelitian tindakan kelas ini bertujuan untuk meningkatkan prestasi belajar siswa khususnya di kelas VIII C SMP Negeri 1 Denpasar.

Menurut teori behaviorisme, belajar adalah perubahan tingkah laku sebagai akibat dari interaksi antara stimulus dan respon atau perubahan yang dialami siswa dalam hal kemampuannya untuk bertingkah laku dengan cara yang baru sebagai hasil interaksi antara stimulus dan respon. Seseorang dianggap telah belajar bila ia telah mampu menunjukkan perubahan tingkah laku. Menurut teori ini, yang terpenting adalah masukan atau input yang berupa stimulus dan keluaran atau output berupa respon. Faktor yang mempengaruhi belajar dalam teori ini adalah penguatan respons (Nahar, 2016). Menurut teori humanistik, belajar adalah untuk memanusiakan manusia atau dapat dikatakan proses aktualisasi diri dengan sebaik-baiknya. Proses belajar dapat dianggap berhasil bila seorang pelajar telah memahami lingkungannya dan dirinya sendiri. Faktor yang berpengaruh disini adalah pengalaman konkrit, pengalaman aktif dan reflektif, konseptualisasi dan eksperimentasi seorang pelajar (Sanusi, 2013).

Faktor-faktor psikologis dalam belajar adalah faktor dari dalam diri anak yang mendorong aktivitas belajarnya yaitu adanya rasa ingin tahu, adanya sifat kreatif dan keinginan untuk selalu maju, keinginan untuk memperbaiki kegagalan, adanya keinginan untuk mendapatkan rasa aman bila menguasai pelajaran dan adanya ganjaran atau hukuman sebagai akhir dari pada belajar (Nidawati, 2013). Selain hal tersebut, faktor pendorong yang besar pengaruhnya dalam belajar adalah adanya minat, bakat, motivasi dan cita-cita. Minat akan menjadikan anak bersemangat untuk belajar sehingga akan menghasilkan prestasi belajar yang baik. Bakat adalah kemampuan individu untuk melakukan suatu tugas yang sedikit sekali tergantung pada latihan mengenai hal tersebut. Adanya minat dan bakat yang tinggi didalam belajar akan menghasilkan tujuan yang dikehendaki dari belajar yang utama yaitu bahwa apa yang dipelajari itu berguna dikemudian hari yakni membantu anak untuk dapat belajar terus dengan cara yang lebih mudah. Dari sini diharapkan seorang anak dapat mengembangkan sikap positif terhadap belajar, penelitian dan penemuan serta pemecahan masalah atas kemampuan sendiri. Motivasi adalah suatu kondisi yang menyebabkan perilaku tertentu dan yang memberi arah dan ketahanan pada tingkah laku tersebut. Seorang anak akan berusaha mencapai suatu tujuan karena terdorong untuk mendapat manfaat dalam melakukan suatu tugas. Cita-cita merupakan pusat dari bermacam-macam kebutuhan yang mampu memobilisasikan energi psikis anak untuk belajar. Dengan mempunyai cita-cita seorang anak akan mempunyai ketertarikan yang tinggi untuk belajar (Nidawati, 2013).

Untuk mencapai prestasi belajar siswa sebagaimana yang diharapkan, maka perlu diperhatikan beberapa faktor yang mempengaruhi prestasi belajar antara lain; faktor yang terdapat dalam diri siswa (faktor intern), dan faktor yang terdiri dari luar siswa (faktor ekstern). Faktor-faktor yang berasal dari dalam diri anak bersifat biologis sedangkan faktor yang berasal dari luar diri anak antara lain adalah faktor keluarga, sekolah, masyarakat dan sebagainya.

Faktor intern adalah faktor yang timbul dari dalam diri individu itu sendiri, adapun yang dapat digolongkan ke dalam faktor intern yaitu kecedersan/intelegensi, bakat, minat, motivasi, status gizi dan penyakit infeksi. (a) Kecerdasan/intelegensi. Kecerdasan adalah kemampuan belajar disertai kecakapan untuk menyesuaikan diri dengan keadaan yang dihadapinya. Kemampuan ini sangat ditentukan oleh tinggi rendahnya intelegensi yang normal selalu menunjukkan kecakapan sesuai dengan tingkat perkembangan sebaya. Adakalanya perkembangan ini ditandai oleh kemajuan-kemajuan yang berbeda antara satu anak dengan anak yang lainnya, sehingga seseorang anak pada usia tertentu sudah memiliki tingkat kecerdasan yang lebih tinggi dibandingkan dengan kawan sebayanya. Oleh karena itu jelas bahwa faktor intelegensi merupakan suatu hal yang tidak diabaikan dalam kegiatan 
belajar mengajar. Kecerdasan merupakan salah satu aspek yang penting, dan sangat menentukan berhasil tidaknya studi seseorang. Kalau seorang murid mempunyai tingkat kecerdasan normal atau di atas normal maka secara potensi ia dapat mencapai prestasi yang tinggi (Syafi'i et al., 2018). (b) Bakat. Bakat adalah kemampuan tertentu yang telah dimiliki seseorang sebagai kecakapan pembawaan. Bakat adalah potensi atau kemampuan kalau diberikan kesempatan untuk dikembangkan melalui belajar akan menjadi kecakapan yang nyata. Tumbuhnya keahlian tertentu pada seseorang sangat ditentukan oleh bakat yang dimilikinya sehubungan dengan bakat ini dapat mempunyai tinggi rendahnya prestasi belajar bidang-bidang studi tertentu. Dalam proses belajar terutama belajat keterampilan, bakat memegang peranan penting dalam mencapai suatu hasil akan prestasi yang baik. (c) Minat. Minat adalah kecenderungan yang tetap untuk memperhatikan dan mengenai beberapa kegiatan. Kegiatan yang dimiliki seseorang diperhatikan terus menerus yang disertai dengan rasa sayang. Menurut (Nurhasanah \& Sobandi, 2016) minat adalah kecenderungan yang menetap dalam subjek untuk merasa tertarik pada bidang/hal tertentu dan merasa senang berkecimpung dalam bidang itu. Minat belajar yang telah dimiliki siswa merupakan salah satu faktor yang dapat mempengaruhi hasil belajarnya. Apabila seseorang mempunyai minat yang tinggi terhadap sesuatu hal maka akan terus berusaha untuk melakukan sehingga apa yang diinginkannya dapat tercapai sesuai dengan keinginannya. (d) Motivasi. Motivasi dalam belajar adalah faktor yang penting karena hal tersebut merupakan keadaan yang mendorong keadaan siswa untuk melakukan belajar. Persoalan mengenai motivasi dalam belajar adalah bagaimana cara mengatur agar motivasi dapat ditingkatkan. Demikian pula dalam kegiatan belajar mengajar sorang anak didik akan berhasil jika mempunyai motivasi untuk belajar. Motivasi adalah segala daya yang mendorong seseorang untuk melakukan sesuatu. Dengan adanya dorongan ini dalam diri siswa akan timbul inisiatif dengan alasan mengapa ia menekuni pelajaran.
Untuk membangkitkan motivasi kepada mereka, supaya dapat melakukan kegiatan belajar dengan kehendak sendiri dan belajar secara aktif. (e) Status Gizi. Status gizi yang baik berperan penting dalam mencapai pertumbuhan badan yang optimal, termasuk pertumbuhan otak yang sangat menentukan kecerdasan seseorang sehingga dampak akhir dari konsumsi gizi yang baik dan seimbang adalah meningkatnya prestasi dan kualitas sumber daya manusia (Supariasa, 2002). (f) Penyakit Infeksi dan Fungsi Panca Indera. Penyakit infeksipun dapat menganggu proses belajar anak, misalnya pilek, sakit gigi, batuk dan lain sebagainya. Keadaan dan fungsi-fungsi dari panca indera yang merupakan syarat agar proses belajar berlangsung dengan baik. Jika tubuh dalam keadaan sehat dan fungsi panca indra baik, maka secara tidak langsung akan berpengaruh terhadap prestasi belajar (Syafi'i et al., 2018).

Faktor ekstern adalah faktor-faktor yang dapat mempengaruhi prestasi belajar yang sifatnya di luar diri siswa, yaitu beberapa pengalaman-pengalaman, keadaan keluarga, lingkungan sekitarnya dan sebagainya. Pengaruh lingkungan ini pada umumnya bersifat positif dan tidak memberikan paksaan kepada individu. Faktor ekstern yang dapat mempengaruhi belajar adalah keadaan keluarga, keadaan sekolah dan lingkungan masyarakat. (a) Lingkungan keluarga. Keluarga merupakan lingkungan terkecil dalam masyarakat tempat seseorang dilahirkan dan dibesarkan. Dalam hal ini Keluarga merupakan lingkungan pendidikan yang pertama, karena dalam keluarga inilah anak pertama-tama mendapatkan pendidikan dan bimbingan, sedangkan tugas utama dalam keluarga bagi pendidikan anak ialah sebagai peletak dasar bagi pendidikan akhlak dan pandangan hidup keagamaan. Oleh karena itu orang tua hendaknya menyadari bahwa pendidikan dimulai dari keluarga. Sedangkan sekolah merupakan pendidikan lanjutan. Peralihan pendidikan informal ke lembaga-lembaga formal memerlukan kerjasama yang baik antara orang tua dan guru sebagai pendidik dalam usaha meningkatkan hasil belajar anak. Jalan kerjasama yang perlu ditingkatkan, 
dimana orang tua harus menaruh perhatian yang serius tentang cara belajar anak di rumah. Perhatian orang tua dapat memberikan dorongan dan motivasi sehingga anak dapat belajar dengan tekun. Karena anak memerlukan waktu, tempat dan keadaan yang baik untuk belajar. (b) Keadaan Sekolah. Sekolah merupakan lembaga pendidikan formal pertama yang sangat penting dalam menentukan keberhasilan belajar siswa, karena itu lingkungan sekolah yang baik dapat mendorong untuk belajar yang lebih giat. Keadaan sekolah ini meliputi cara penyajian pelajaran, hubungan guru dengan siswa, alat-alat pelajaran dan kurikulum. Hubungan antara guru dan siswa kurang baik akan mempengaruhi hasil-hasil belajarnya. (c) Lingkungan Masyarakat. Selain orang tua, lingkungan juga merupakan salah satu faktor yang tidak sedikit pengaruhnya terhadap hasil belajar siswa dalam proses pelaksanaan pendidikan. Karena lingkungan alam sekitar sangat besar pengaruhnya terhadap perkembangan pribadi anak, sebab dalam kehidupan sehari-hari anak akan lebih banyak bergaul dengan lingkungan dimana anak itu berada. Lingkungan masyarakat dapat menimbulkan kesukaran belajar anak, terutama anakanak yang sebayanya. Apabila anak-anak yang sebaya merupakan anak-anak yang rajin belajar, maka anak akan terangsang untuk mengikuti jejak mereka. Sebaliknya bila anak-anak di sekitarnya merupakan kumpulan anak-anak nakal yang berkeliaran tiada menentukan anakpun dapat terpengaruh pula. Dengan demikian dapat dikatakan lingkungan membentuk kepribadian anak, karena dalam pergaulan sehari-hari seorang anak akan selalu menyesuaikan dirinya dengan kebiasaankebiasaan lingkungannya. Oleh karena itu, apabila seorang siswa bertempat tinggal di suatu lingkungan temannya yang rajin belajar maka kemungkinan besar hal tersebut akan membawa pengaruh pada dirinya, sehingga ia akan turut belajar sebagaimana temannya.

Model Pembelajaran learning community (masyarakat belajar). Joyce \& Weil (1996) dalam bukunya "Models of Teaching" memaparkan beberapa model pembelajaran dengan unsur-unsur dasar, yaitu: (1) Syntax, yaitu langkah-langkah operasional pembelajaran, (2) social system, adalah suasana dan norma yang berlaku dalam pembelajaran, (3) principles of reaction, menggambarkan bagaimana seharusnya guru memandang, memperlakukan, dan merespon siswa, (4) support system, segala sarana, bahan, alat, atau lingkungan belajar yang mendukung pembelajaran, (5) instructional dan nurturant effects-hasil belajar yang diperoleh langsung berdasarkan tujuan yang disasar (instructional effects) dan hasil belajar di luar yang disasar (nurturant effects). Lima unsur tersebut dicoba dipaparkan pada bagian ini sehingga tergambar Model Learning Community yang dimaksud dalam penelitian ini.

Model learning community sulit didefinisikan secara jelas karena masih baru dan bersifat kompleks. Konsep learning community tidaklah baru sama sekali. Konsep ini diperkenalkan oleh Alexander Meiklejohn pada tahun 1920. Pengembangan selanjutnya juga dilakukan pada tahun 1960 dan 1980. Bielaczyc \& Collins (2009) mengungkapkan bahwa komunitas belajar (learning communities) adalah suatu budaya belajar yang melibatkan setiap siswa untuk melakukan upaya-upaya kolektif dalam membangun pemahaman.

Langkah-langkah model group investigation sebagai berikut. Grouping (menetapkan jumlah anggota komunitas, menentukan sumber, memilih topik dan merumuskan permasalahan). Planning (menetapkan apa yang akan dipelajari, siapa melakukan apa, apa tujuannya). Investigation (saling tukar informas dan ide, berdiskusi, klarifikasi, mengumpulkan informasi, menganalisis data, membuat inferensi). Organizing (anggota komunitas menulis laporan, merencanakan presentasi laporan, penentuan penyaji, moderator dan notulis). Presenting (salah satu komunitas menyajikan, komunitas lain mengamati, mengevaluasi, mengklarifikasi, mengajukan pertanyaan atau tanggapan). Evaluating (masing-masing pebelajar melakukan koreksi terhadap laporan masing-masing berdasarkan hasil diskusi kelas, pebelajar dan guru berkolaborasi mengevaluasi pembelajaran yang dilakukan, melakukan 
penilaian hasil belajar yang difokuskan pada pencapaian pemahaman).

\section{METODE}

Subyek penelitian adalah siswa kelas VIII C 1 SMP Negeri 1 Denpasar dengan jumlah siswa di kelas ini adalah 45 orang yang terdiri dari 25 orang laki - laki dan 20 orang perempuan. Siswa kelas VIII $C$ sebagai subyek penelitian ini memiliki karakteristik yang heterogen. Heterogen baik dalam segi kemampuan intelegensi, motivasi belajar, latar belakang keluarga, maupun sifat dan wataknya. Dari segi watak ada beberapa siswa yang memiliki watak sulit diatur, sehingga kadang-kadang menyulitkan guru pada saat pembelajaran berlangsung. Namun secara umum memiliki kepribadian yang cukup baik.

Permasalahan tersebut mungkin dikarenakan semangat belajar yang kurang. Keadaan tersebut dapat dilihat keadaan sehari-hari, di mana siswa sering mengeluh pusing dan bosan bila diajak belajar IPS. Permasalahan inilah yang mendorong peneliti mengangkat mata pelajaran IPS kompetensi dasar tentang pengertian konflik, menganalisis faktor penyebab konflik, membedakan bentuk - bentuk konflik, mendiskripsikan dampak konflik, mengidentifikasi cara pengendalian konflik untuk mendapatkan informasi penting sebagai obyek penelitian.

Penelitian ini menggunakan rancangan Penelitian Tindakan Kelas (PTK) (Ni'mah, 2017). PTK adalah penelitian yang dilakukan oleh guru di dalam kelasnya sendiri melalui refleksi diri, dengan tujuan untuk memperbaiki kinerjanya sebagai guru, sehingga hasil belajar siswa menjadi meningkat. Penelitian Tindakan Kelas merupakan penelitian yang bersiklus, yang terdiri dari perencanaan, pelaksanaan, observasi, dan refleksi yang dilakukan secara berulang, hal ini dapat digambarkan sebagai berikut:

Pertama, proses penelitian tindakan kelas ditik beratkan pada prestasi belajar siswa dalam proses pembelajaran melalui pendekatan learning community, melalui strategi ini diharapkan dapat meningkatkan kemampuan siswa dalam meraih prestasi belajar.
Kedua, tempat, waktu dan subyek penelitianPenelitian dilaksanakan di SMP Negeri 1 Denpasar, Kecamatan Denpasar Timur, Kota Denpasar, Provinsi Bali. Penelitian dilaksanakan selama 4 bulan mulai dari minggu ke 2 bulan Januari 2019 sampai dengan minggu ke 4 bulan Mei 2019. Subyek penelitian adalah siswa kelas VIII C SMP Negeri 1 Denpasar dengan jumlah siswa di kelas ini adalah 45 orang yang terdiri dari 20 orang laki - laki dan 25 orang perempuan. Ketiga, sumber data penelitian adalah data primer yang diperoleh melalui angket, wawancara dan observasi pada siswa kelas VIII C SMP Negeri 1 Denpasar pada tahun ajaran 2018/2019. Keempat, teknik dan alat pengumpulan data dilakukan dengan Teknik angket, observasi dan wawancara. Kelima, validasi dilakukan pada angket, observasi dan wawancara. Keenam, analisis data yang dipergunakan dalam penelitian ini adalah analisis kuantitatif dan kualitatif. Analisis digunakan terhadap data hasil penelitian tahap pra siklus, siklus pertama, dan siklus ke dua. Teknik analisis dilakukan dengan membandingkan seberapa besar selisih nilai yang diperoleh siswa dalam mengikuti ulangan harian dan aktifitas siswa selama proses pembelajaran pada setiap tahap.

Penelitian tindakan kelas dilaksanakan dalam dua siklus. Setiap siklus terdiri dari empat langkah yaitu perencanaan (planning), pelaksanaan (actuating), observasi (observing), dan refleksi (reflecting). Prosedur penelitian tindakan kelas dilakukan secara bertahap mulai dari kegiatan awal (pra siklus), pelaksanaan tindakan siklus pertama dan siklus ke dua.

Tahapan Penelitian Tindakan Kelas yaitu, Pertama, langkah Tindakan pada Kegiatan Pra Siklus meliputi, menginformasikan kepada kelas VIII C SMP Negeri 1 Denpasar pada saat proses pembelajaran akan dimulai bahwa kelasnya dijadikan penelitian, mengadakan ulangan harian atau pretest, menganalisis hasil ulangan, mengamati aktifitas siswa baik sikap dan perilakunya selama mengikuti proses pembelajaran maupun ulangan.

Melakukan penelitian. 
Kedua, tahap siklus I yaitu kegiatan penelitian tindakan kelas tahap siklus pertama dilaksanakan berdasarkan hasil kegiatan tahap pra siklus. Tahap siklus pertama diterapkan tindakan penelitian dengan menggunakan pendekatan learning community yaitu sebagai berikut:

\section{Tahap Perencanaan}

Penyusunan perencanaan mengacu pada peningkatan prestasi dan partisipasi belajar siswa mata pelajaran IPS. Perencanaan penelitian tindakan kelas menggunakan langkah-langkah meliputi mengkondisikan kelas agar dapat digunakan untuk penelitian tindakan kelas dan menyiapkan perangkat penelitian, antara lain: Menyusun angket penelitian. Menyusun pedoman observasi. Menyusun pedoman wawancara atau panduan wawancara. Menyiapkan pedoman analisis data.

\section{Tahap Tindakan}

Melaksanakan penelitian tindakan kelas, dengan menggunakan skenario membentuk kelompok belajar berdasarkan hiterogenitas jenis kelamin, kemampuan, memberi penjelasan kepada kelompok tentang materi yang harus didiskusikan, dan yang dilakukan dalam kelompok, menugaskan kelompok untuk membuat kesimpulan materi yang didiskusikan dalam kelompok, membimbing kelompok dalam mengerjakan tugas diskusi, rangkuman yang dibuat harus dihubungkan dengan kondisi riil di masyarakat setempat, masing-masing kelompok diminta untuk mempresentasikan hasil kerja kelompok, kelompok lain diberi kesempatan untuk memberi tanggapan hasil kelompok lain, meminta kelompok mengumpulkan hasil kerja kelompok dan membuat kesimpulan bersama dalam kelas.

\section{Tahap Pengamatan atau Observasi}

Peneliti mengadakan pengamatan atau observasi selama proses pembelajaran dan laporan hasil kerja kelompok siswa berupa rangkuman hasil diskusi kelompok, meliputi bagaimana reaksi siswa saat menerima tugas mendiskusikan materi, aktifitas siswa selama diskusi kelompok, partisipasi siswa dalam membuat laporan hasil kerja, produk siswa yang berupa laporan hasil kerja kelompok, partisipasi siswa selama diskusi kelas dan artisipasi siswa selama membuat laporan bersama.

\section{Tahap Refleksi}

Berdasarkan hasil pengamatan atau observasi dan wawancara selama kagiatan siklus pertama, diperoleh data aktifitas dan hasil kerja siswa selama diskusi. Data tersebut digunakan sebagai dasar untuk menyusun rencana tindakan pada siklus ke dua. Kegiatan refleksi dilakukan untuk mengetahui kelemahan tindakan siklus pertama, apakah telah terjadi perubahan atau belum, dan bagaimana cara mengatasi kelemahan-kelamahan yang terjadi pada siklus tersebut, selanjutnya digunakan untuk merencanakan tindakan siklus ke dua.

Ketiga, siklus II dilaksanakan berdasarkan refleksi dari pelaksanaan tindakan siklus pertama. Pelaksanaan tindakan siklus ke dua dilaksanakan dengan tujuan memperbaiki kelemahan kelemahan tindakan siklus pertama. Adapun langkah-langkah tindakan siklus ke dua adalah sebagai berikut :

\section{Tahap Perencanaan}

Kegiatan perencanaan siklus ke dua adalah menyusun rencana atau skenario tindakan ulang berdasarkan evaluasi dan catatan yang didapat berdasarkan hasil refleksi siklus pertama, menyiapkan perangkat tindakan berupa lembar pengumpulan data dan perangkat analisis data, melaksanakan rencana tindakan siklus ke dua dengan pendekatan learning community

Tahap Tindakan

Pada siklus ke dua, peneliti melakukan tindakan yang berupa perbaikan dari tindakan siklus pertama, dengan menggunakan pendekatan yang sama seperti siklus pertama yakni pendekatan learning community yang lebih bervariasi.

Tahap observasi atau pengamatan

Kegiatan yang dilakukan pada tahap ini yaitu peneliti melakukan pengamatan atau observasi dengan menggunakan lembar pengamatan terhadap proses diskusi siswa dan mengumpulkan data hasil diskusi siswa baik diskusi kelompok maupun diskusi kelas.

\section{Tahap Refleksi}

Kegiatan yang dilakukan pada saat refleksi adalah memeriksa dan menilai hasil diskusi siswa, mengidentifikasi kelemahan yang timbul pada tindakan siklus kedua berlangsung, dan melakukan evaluasi 
secara menyeluruh terhadap proses dan hasil kerja siswa selama siklus ke dua

\section{HASIL DAN PEMBAHASAN}

Deskripsi Hasil Belajar Prasiklus

Hasil pembelajaran kondisi awal IPS dengan kompetensi dasar mendeskripsikan dan menjelaskan pengertian konflik, menganalisis faktor penyebab konflik, membedakan bentuk - bentuk konflik, mendiskripsikan dampak konflik, mengidentifikasi cara pengendalian konflik melalui pendekatan learning community diperoleh data dimana pada masa pra siklus mencapai rata - rata 69,33 dan hanya 42,22 persen siswa mencapai nilai 70 atau lebih besar 70 . Padahal idealnya minimal harus mencapai 100 persen siswa mendapat 70 atau di atas 70 . Menurut teori kognitivisme, belajar tidak sekedar melibatkan hubungan antara stimulus dan respon, lebih dari itu belajar melibatkan proses berfikir yang sangat kompleks. IImu pengetahuan dibangun dalam diri seorang individu melalui proses interaksi yang berkesinambungan dengan lingkungan. Asumsi dasar teori ini adalah bahwa setiap orang mempunyai pengalaman dan pengetahuan di dalam dirinya yang tertata dalam bentuk struktur kognitif. Proses belajar akan berjalan dengan baik bila materi pelajaran yang baru beradaptasi (bersinambung) secara "klop" dengan struktur kognitif yang sudah dimiliki oleh seorang anak (Pahliwandari, 2016). Menurut aliran sibernetik, belajar adalah proses pengolahan informasi. Teori ini berkembang sejalan dengan perkembangan ilmu informasi. Menurut teori ini tidak ada satu proses belajar pun yang ideal untuk segala situasi, yang cocok untuk semua siswa. Dengan kata lain sebuah informasi mungkin akan dipelajari seorang siswa dengan cara belajar yang berbeda. Menurut aliran skolastik belajar pada hakekatnya adalah mengulang-ulang bahan yang harus dipelajari. Dengan diulang-ulang maka bahan pelajaran akan semakin diingat atau dikuasai. Hal ini sama dengan pendapat ahli-ahli psikologi daya, belajar adalah proses melatih daya jiwa yaitu mengerjakan sesuatu yang sama berulang-ulang dengan jalan melatihnya, proses mengerjakan sesuatu berulang-ulang sehingga daya ingatan akan menjadi lebih tinggi kalau berulang-ulang mengingat sesuatu tersebut (Dalyono, 2012). Jadi belajar merupakan perubahan persepsi dan pemahaman berupa perubahan tingkah laku, mendapatkan kecakapan baru yang berlangsung lambat laun melalui usaha aktualisasi diri sebaik-baiknya yang terjadi secara berulang-ulang (Purnamawati, 2017). Belajar juga merupakan suatu pengolahan informasi yang diterima seseorang sebagai bukti pengaktualisasian diri seseorang. Prestasi belajar adalah penguasaan pengetahuan atau ketrampilan yang dikembangkan melalui mata pelajaran, umumnya ditujukan dengan nilai yang diberikan oleh guru. Prestasi belajar merupakan hasil dari proses kegiatan belajar. Untuk mengetahui prestasi belajar dapat dilakukan melalui proses penilaian hasil belajar dengan menggunakan tes maupun evaluasi (Syafi'i et al., 2018). Dalam kehidupan sehari-hari umumnya seseorang akan dihargai melalui prestasi belajarnya atau keberhasilannya.

Pengukuran adalah pemberian angka kepada suatu atribut atau karakteristik tertentu yang dimiliki oleh seseorang, hal atau obyek tertentu menurut aturan atau formulasi yang jelas. Jadi pengukuran prestasi belajar (Purnamawati, 2014) adalah pemberian angka atau skala tertentu menurut suatu aturan atau formula tertentu terhadap penguasaan pengetahuan atau ketrampilan yang dikembangkan melalui pelajaran. Pengukuran ini digunakan oleh seorang pendidik atau guru untuk melakukan penilaian terhadap hasil belajar anak didiknya, baik menggunakan instrumen tes maupun non tes. Tes adalah suatu pernyataan atau tugas atau seperangkat tugas yang direncanakan untuk memperoleh informasi tentang atribut pendidikan yang setiap butir pertanyaan atau tugas tersebut mempunyai jawaban atau ketentuan tertentu yang dianggap benar (Syafi'i et al., 2018).

Instrumen non tes lebih ditekankan pada sikap seorang anak didik, misalnya sopan santun, budi pekerti dan hubungan sosial dengan teman dan lingkungan. Penilaian hasil belajar dapat dilakukan dengan baik dan benar bila menggunakan informasi yang diperoleh melalui 
pengukuran hasil belajar dengan menggunakan tes sebagai alat ukurnya. Secara garis besar penilaian dapat dibagi menjadi dua, yaitu penilaian formatif dan penilaian sumatif. Penilaian formatif digunakan untuk memantau sejauh manakah proses pendidikan telah berjalan sebagaimana yang direncanakan. Sedangkan penilaian sumatif dilakukan untuk mengetahui sejauh mana peserta didik telah dapat berpindah dari satu unit keunit berikutnya (Rapi, 2016). Dalam penelitian ini yang digunakan sebagai instrumen penelitian adalah nilai ulangan harian, yaitu nilai pada kegiatan sehari hari pada uji kompetensi. Hal ini dikarenakan nilai ulangan harian memberi gambaran yang jelas tentang kemampuan belajar seorang anak atau peserta didik. Nilai ulangan harian yang di ambil adalah nilai ulangan harian mata pelajaran IPS. Adapun caranya untuk menentukan prestasi belajar anak yaitu dengan mengambil nilai mentah hasil ulangan harian. Setelah itu barulah kita tentukan prestasi belajar anak dengan menggunakan batasan nilai KKM (Kriteria Ketuntasan Minimal). Di sini peneliti mengambil nilai ulangan karena nilai ulangan harian adalah nilai asli yang belum ditambah oleh guru sehingga hasilnya akan menjadi lebih valid.

\section{Deskripsi Proses pembelajaran}

Proses pembelajaran kondisi awal siswa kelas VIII C SMP Negeri 1 Denpasar pada mata pelajaran IPS tentang pengertian konflik, menganalisis faktor penyebab konflik, membedakan bentuk - bentuk konflik, mendiskripsikan dampak konflik, mengidentifikasi cara pengendalian konflik kurang berhasil karena rata - rata kelas mencapai 69,33 dan hanya 42,22 persen siswa mencapai ketuntasan atau nilainya lebih dari 70. Padahal idealnya ketuntasan klasikal adalah 85 persen dan KKM harus 70.

Proses belajar dipengaruhi oleh banyak faktor, diantaranya adalah faktor yang berasal dari luar diri anak (eksternal) dan faktor yang berasal dari dalam diri anak (internal). Faktor dari luar diri anak ada dua yaitu faktor-faktor non sosial dan faktorfaktor sosial, sedangkan faktor internal digolongkan menjadi dua yaitu faktor-faktor fisiologis dan faktor-faktor psikologis. Faktor-faktor non sosial dalam belajar meliputi keadaan suhu, udara, cuaca, waktu (pagi, siang, malam), tempat (gedungnya, letaknya), alat-alat yang dipakai untuk belajar (alat-alat tulis, buku, alat-alat peraga dan lain-lain). Kesemua faktor tersebut mempunyai syarat-syarat tertentu, misalnya lingkungan belajar harus jauh dari kebisingan, bangunan harus memenuhi standar dalam ilmu kesehatan sekolah, alatalat pelajaran sekolah harus diusahakan untuk memenuhi syarat-syarat menurut pertimbangan didaktis, psikologis dan paedagogis (Ernida, 2015).

Faktor-faktor sosial dalam belajar adalah faktor manusia atau sesama manusia, baik manusia itu ada atau tidak ada secara langsung. Kehadiran orang lain dalam belajar dapat menganggu konsentrasi pada seseorang yang sedang belajar sehingga perhatian tidak dapat ditujukan pada hal yang dipelajari atau aktivitas belajar itu semata-mata (Ernida, 2015). Faktor-faktor fisiologis dalam belajar dapat dibedakan menjadi dua macam, yaitu kesehatan jasmani pada umumnya dan keadaan fungsi-fungsi fisiologis tertentu. Keadaan kesehatan jasmani pada umumya melatar belakangi aktivitas belajar dan akan mempengaruhi hasil belajar, misalnya tubuh kurang segar dan lelah. Hal yang perlu diperhatikan adalah anak harus mendapatkan nutrisi yang cukup agar kesehatan jasmaninya baik. Selain nutrisi beberapa penyakit infeksipun dapat menganggu proses belajar anak, misalnya pilek, sakit gigi, batuk dan lain sebagainya. Keadaan fungsi fisiologis tertentu disini adalah fungsi-fungsi dari panca indera yang merupakan syarat agar proses belajar berlangsung dengan baik. Dalam proses belajar, panca indera yang paling memegang peranan penting dalam diri anak adalah mata dan telinga. Mata berfungsi sebagai alat penglihatan yang merupakan salah satu penunjang perkembangan kemampuan anak, yaitu melalui proses membaca ataupun pengamatan terhadap segala hal yang ada disekitarnya. Begitu juga telinga, indera ini mempunyai arti penting dalam proses belajar anak. Hal ini dikarenakan telinga berfungsi untuk mendengarkan suara, kata, bunyi yang 
menyebabkan anak meniru sehingga menambah kemampuan dalam diri anak (Daryanto, 2009).

\section{Perencanaan Tindakan}

Pelaksanaan pembelajaran Penelitian Tindakan Kelas (PTK) siklus I dilaksanakan dalam tiga kali pertemuan. Pertemuan pertama dilaksanakan tanggal 16 Januari 2019 , pertemuan kedua tanggal 18 Januari 2019 dan pertemuan ketiga tanggal 23 Januari 2019. Sebelum melaksanakan tindakan pembelajaran, dilakukan persiapan terakhir. Langkah awal dalam perencanaan adalah peneliti memeriksa Rencana Pelaksanaan Pembelajaran (RPP) yang telah disusun, dibaca ulang, mencermati setiap butir yang akan direncanakan.

Peneliti memeriksa skenario pembelajaran yang terdapat dalam RPP yang akan diimplementasikan melalui kegiatan pembelajaran dari kegiatan awal sampai kegiatan akhir. Pada kegiatan awal pertemuan pertama dilaksanakan tanggal 16 Januari 2019. Kegiatan awal dilaksanakan kurang lebih 10 menit, yaitu memberikan salam, memeriksa kehadiran siswa, mengkondisikan siswa agar siap menerima pelajaran, memotivasi siswa, memberikan apersepsi untuk memusatkan perhatian siswa pada materi pembelajaran. Peneliti menyampaikan materi dan tujuan pembelajaran yang akan dilaksanakan. Kegiatan inti siklus I pertemuan pertama dilaksanakan selama 40 menit. Guru membentuk kelompok diskusi berdasarkanlokasi tempat duduk siswa, untuk melaksanakan diskusi sesuai permasalahan yang ada. Ketua kelompok mengambil lembar kerja siswa yang telah disiapkan untuk di diskusikan secara bersama - sama di dalam kelompok.

Guru mengawasi siswa yang sedang melakukan diskusi. Setelah kerja kelompok selesai, dilanjutkan dengan diskusi kelas untuk saling mencocokkan hasil kerjanya. Setiap kelompok diberi kesempatan untuk menyampaikan hasil diskusi dan kelompok lain memberikan tanggapan.

Setelah semua kelompok selesai presentasi, guru mengulas materi dan hasil kerja siswa. Dengan bimbingan guru, siswa membuat kesimpulan dari kegiatan yang telah dilaksanakan.
Tiga ide pokok dalam profesional learning community meliputi: 1) memastikan bahwa siswa belajar, 2) menciptakan budaya kolaboratif dan 3) fokus pada hasil (Munazah et al., 2015).

Menurut Lenning dan Ebbers terdapat empat bentuk learning community. Salah satunya adalah learning community yang diterapkan dalam pembelajaran kelas. Pada bentuk ini, Model Learning Community sebagai lokus pembangunan komunitas yang dicirikan dengan teknik-teknik pembelajaran kooperatif dan aktivitas pembelajaran proses kelompok sebagai sebuah pendekatan pendidikan yang terintegrasi. Sesuai dengan latar belakang dan tujuan penelitian, Model Learning Community yang dimaksud pada penelitian ini adalah bentuk learning community yang diterapkan dalam pembelajaran di kelas.

Secara lebih sfesifik, classroom learning communities (García-Carrión \& Díez-Palomar, 2015) sebagai sesuatu yang mendorong: (1) penghargaan terhadap perbedaan pelajar (budaya, bahasa, umur, dan sebagainya) dalam kelas; (2) kesediaan siswa untuk mengambil risiko intelektual dalam lingkungan belajar; (3) tujuan bersama untuk meningkatkan pengetahuan dan keterampilan secara berkesinambungan; dan (4) sebuah keterkaitan antara pelajar yang mengarah ke identitas umum dan rasa memiliki (sense of belonging). Karakteristik ini digunakan sebagai kerangka untuk mengembangkan strategi instruksional pengembangan learning community.

Learning community dilandasi oleh konstruktivisme sosial. Kontruktivisme sosial merupakan paradigma pembelajaran yang digagas oleh Vygotsky, pembelajaran berfokus pada proses dan interaksi dalam konteks sosial. Interaksi dan proses sosial mejadi perhatian dalam mencapai tujuan pembelajaran. Hal senada diungkapkan oleh (Salazar et al., 2010) learning community merupakan suatu konsep terciptanya masyarakat belajar di sekolah, yakni proses belajar membelajarkan antara guru dengan guru, guru dengan siswa, siswa dengan siswa, dan bahkan antara masyarakat sekolah dengan masyarakat di luar sekolah, agar prestasi belajar siswa dapat ditingkatkan. Learning community 
berusaha menggeser pembelajaran yang bersifat individual menjadi pembelajaran yang bersifat sosial. Ini berarti iklim kompetitif dalam kelas harus diubah menjadi iklim sosial, sehingga tidak terjadi kesenjangan intelektual dan pengalaman di antara siswa.

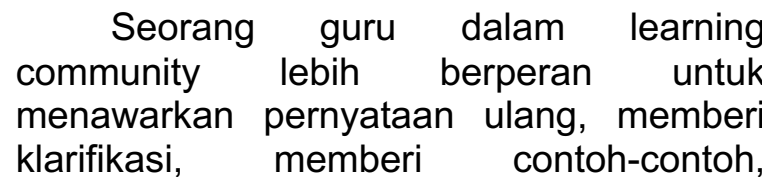
memberikan ringkasan, memotivasi siswa untuk bekerja sebaik mungkin, serta menjadi pendengar yang aktif. Ini memberikan dasar bagaimana seharusnya guru memandang, memperlakukan, dan merespon siswa. Engstrom \& Tinto (2008) menunjukkan bahwa aspek dalam komunitas belajar (learning community) yang berkontribusi terhadap keberhasilan belajar adalah lingkungan yang aman dan mendukung proses pembelajaran. Lingkungan ini tercipta dengan menerapkan empat strategi kunci dalam menciptakan komunitas belajar. Empat strategi kunci itu meliputi (1) penggunaan strategi pembelajaran aktif dan kolaboratif, (2) pengembangan kurikulum yang koheren dan terpadu, (3) pengintegrasian layanan dan program satuan pendidikan dalam komunitas belajar, dan (4) pemberian dorongan dan dukungan kepada pebelajar untuk memiliki harapan yang tinggi.

Berdasarkan penelitian Engstrom \& Tinto, dapat diambil dua hal penting dalam mengembangkan Model Learning Community. Pertama, bahwa seting pembelajaran kolaboratif sangat penting digunakan dalam model ini. Kedua, peran guru sebagai motivator dalam menumbuhkan ekspektasi dan rasa percaya diri siswa yang menjadi ciri yang khas dalam Model Learning Community. Pembelajaran kolaboratif dan eksperensial merupakan kunci dari learning community. Sebagai sebuah model pembelajaran di kelas, konsep Panccuci sesuai untuk diadopsi dalam model ini. Learning community merupakan sebuah kelompok yang anggotanya terlibat secara aktif untuk belajar satu sama lain dengan karakteristik individu yaitu (1) kolaboratif mindset, (2) fokus pada pembelajaran, (3) fokus pada hasil, (4) orientasi kepada tindakan, (5) penemuan yang kolektif, (6) informasi yang relevan dan (7) komitmen untuk peningkatan berkelanjutan.

Tastra et al. (2009) mengembangkan model-model komunitas belajar berdasarkan filosofi John Dewey, psikologi behavioristik, psikologi sosial, dan psikologi kognitif. Konsep Dewey (Maiaweng, 2009) dalam pendidikan bahwa kelas seharusnya merupakan cermin masyarakat dan berfungsi sebagai laboratorium untuk belajar tentang kehidupan nyata. Gagasan Dewey kemudian dikembangkan oleh Thelen menjadi teknik group investigation. Konsep Dewey dan pengembangan oleh Thelen inilah yang mendasari pengembangan model komunitas belajar group investigation oleh Tastra dan kawankawan. Selanjutnya, Guru memberikan saran dan tindak lanjut untuk pelajaran berikutnya. Guru memberi tugas pekerjaan rumah pada siswa untuk menyelesaikan yang akan dibahas pada pertemuan selanjutnya.

\section{Pelaksanaan Tindakan Siklus I}

Siswa dengan bimbingan guru mengkaji dan menelaah masalah yang ada pada materi tentang pengertian konflik, menganalisis faktor penyebab konflik, membedakan bentuk - bentuk konflik, mendiskripsikan dampak konflik, mengidentifikasi cara pengendalian konflik, kemudian dilanjutkan dengan menjawab pertanyaan pada lembar kerja siswa. Siswa mengerjakan LKS, beberapa siswa melaporkan hasil kerjanya di depan kelas bergantian dan siswa lain yang belum maju memberikan tanggapan, sanggahan, pertanyaan dan pendapat yang berbeda kepada siswa yang sedang melaporkan hasil kerjanya. Selama kegiatan pembelajaran yang berlangsung selama 3 kali pertemuan, semua kegiatan berjalan lancar dan tidak ada kendala yang menganggu proses belajar mengajar.

\section{Hasil Pengamatan Siklus I}

Hasil belajar pada siklus I terdapat kenaikan prestasi belajar berupa rata-rata kelas menjadi 78,89 dan sebanyak 80 persen siswa memperoleh nilai tuntas. Nilai terendah adalah 50 dan nilai tertinggi adalah 100. Dalam pembelajaran IPS siswa 
mulai tertarik untuk mengikuti diskusi walaupun masih ada yang bermain - main, pasif dalam diskusi. Dengan model pembelajaran learning community mulai ada perubahan prestasi belajar siswa ke arah peningkatan. Dengan memperhatikan hasil pengamatan terhadap siswa diperoleh halhal sebagai berikut. Pertama, dalam proses pembelajaran IPS di Kelas VIII C SMP Negeri 1 Denpasar terdapat peningkatan prestasi belajar dari nilai rata - rata 69,33 menjadi 78,89 dan jumlah siswa yang tuntas dari 42,22 persen menjadi 80 persen. Kedua, tetap meningkatkan prestasi belajar siswa dengan menggunakan model pembelajaran learning community.

\section{Perencanaan Tindakan Siklus II}

Pelaksanaan kegiatan dilaksanakan pada tanggal 30 Januari 2019, 1 Februari 2019, dan 6 Februari 2019. Sebelum melaksanakan tindakan perbaikan, dilakukan persiapan terakhir. Langkah awal dalam perencanaan adalah peneliti memeriksa RPP yang telah disusun, dibaca ulang, mencermati setiap butirnya. Yang tidak kalah pentingnya adalah semua perencanaan harus dimatangkan dan sarana prasarana dipersiapkan dengan baik agar kegiatan PBM tidak menemukan hambatan yang dapat menganggu proses penyusunan PTK ini. Kegiatan awal dilaksanakan kurang lebih 10 menit, yaitu memberikan salam, memeriksa kehadiran siswa, mengkondisikan siswa agar siap menerima pelajaran, memotivasi siswa, memberikan apersepsi untuk memusatkan perhatian siswa pada materi pembelajaran. Peneliti menyampaikan materi dan tujuan pembelajaran yang akan dilaksanakan. Kegiatan inti siklus II pertemuan pertama dilaksanakan selama 40 menit. Guru membentuk kelompok diskusi berdasarkan lokasi tempat duduk siswa, untuk melaksanakan diskusi sesuai permaslahan yang ada. Ketua kelompok mengambil lembar kerja siswa yang telah disiapkan untuk didiskusikan secara bersama - sama di dalam kelompok.

Guru mengawasi siswa yang sedang melakukan diskusi. Setelah kerja kelompok selesai, dilanjutkan dengan diskusi kelas untuk saling mencocokkan hasil kerjanya. Setiap kelompok diberi kesempatan untuk menyampaikan hasil diskusi dan kelompok lain memberikan tanggapan.

Setelah semua kelompok selesai presentasi, guru mengulas materi dan hasil kerja siswa. Dengan bimbingan guru, siswa membuat kesimpulan dari kegiatan yang telah dilaksanakan. Selanjutnya guru memberikan saran dan tindak lanjut untuk pelajaran berikutnya. Guru memberi tugas pekerjaan rumah pada siswa untuk menyelesaikan yang akan dibahas pada pertemuan selanjutnya.

Siswa dengan bimbingan guru mengkaji dan menelaah masalah yang ada pada materi tentang pengertian konflik, faktor penyebab konflik, bentuk-bentuk konflik, dampak konflik, dan cara pengendalian konflik, kemudian dilanjutkan dengan menjawab pertanyaan pada lembar kerja siswa. Siswa mengerjakan LKS, beberapa siswa melaporkan hasil kerjanya di depan kelas bergantian dan siswa lain yang belum maju memberikan tanggapan, sanggahan, pertanyaan dan pendapat yang berbeda kepada siswa yang sedang melaporkan hasil kerjanya. Selama kegiatan pembelajaran yang berlangsung selama 3 kali pertemuan, semua kegiatan berjalan lancar dan tidak ada kendala yang menganggu proses belajar mengajar.

\section{Hasil Pengamatan Siklus II}

Hasil belajar pada siklus II terdapat kenaikan prestasi belajar berupa rata-rata kelas menjadi 87,78 dan sebanyak 100 persen siswa memperoleh nilai tuntas. Nilai terendah adalah 80 dan nilai tertinggi adalah 100. Dalam pembelajaran IPS siswa sangat tertarik untuk mengikuti diskusi, siswa yang suka bermain - main tidak ada, siswa sangat aktif dalam diskusi. Dengan model pembelajaran learning community perubahan prestasi belajar siswa ke arah peningkatan sangat dirasakan. Dengan memperhatikan hasil pengamatan terhadap siswa diperoleh hal-hal sebagai berikut:

Pertama, dalam proses pembelajaran IPS di Kelas VIII C SMP Negeri 1 Denpasar terdapat peningkatan prestasi belajar dari nilai rata - rata 69,33 menjadi 87,78 dan jumlah siswa yang tuntas dari 42,22 persen menjadi 100 persen. Kedua, tetap meningkatkan prestasi belajar siswa 
dengan menggunakan model pembelajaran learning community.

\section{SIMPULAN DAN SARAN}

Hasil pembelajaran kondisi awal IPS dengan kompetensi dasar mendeskripsikan dan menjelaskan pengertian konflik, menganalisis faktor penyebab konflik, membedakan bentuk - bentuk konflik, mendiskripsikan dampak konflik, mengidentifikasi cara pengendalian konflik melalui pendekatan learning community diperoleh data di mana pada masa prasiklus mencapai rata - rata 69,33 dan hanya 42,22 persen siswa mencapai nilai 70 atau lebih dari 70. Padahal idealnya minimal harus mencapai 100 persen siswa mendapat 70 atau di atas 70 .

Hasil belajar pada siklus I terdapat kenaikan prestasi belajar berupa rata - rata kelas menjadi 78,89 dan sebanyak 80 persen siswa memperoleh nilai tuntas. Nilai terendah adalah 50 dan nilai tertinggi adalah 100.

Hasil belajar pada siklus II terdapat kenaikan prestasi belajar berupa rata - rata kelas menjadi 87,78 dan sebanyak 100 persen siswa memperoleh nilai tuntas. Nilai terendah adalah 80 dan nilai tertinggi adalah 100. Karena dalam penelitian ini terjadi peningkatan prestasi belajar siswa , maka peneliti berkesimpulan bahwa model pembelajaran learning community sangat cocok digunakan dalam pembelajaran IPS.

\section{Saran}

Guru hendaknya selalu mencari dan menyesuaikan model pembelajaran dengan materi yang disampaikan, guru sebagai pendidik hendaklah juga memahami karakteristik dan kemampuan siswa, karena masing-masing siswa pada dasarnya mempunyai karakter dan kemampuan yang berbeda-beda.

Karena kegiatan ini sangat bermanfaat khususnya bagi guru dan siswa, maka diharapkan kegiatan ini dapat dilakukan secara berkesinambungan dalam pembelajaran IPS .

\section{DAFTAR PUSTAKA}

Dalyono, M. (2012). Psikologi Pendidikan.
Jakarta: PT Rineka Cipta.

Ernida. (2015). Upaya Peningkatan Prestasi Belajar IPS Melalui Pendekatan Learning Community Di SMP Negeri 2, Banda Aceh. Jurnal Pencerahan, 9(2), 131-152.

García-Carrión, R., \& Díez-Palomar, J. (2015). Learning Communities: Pathways for Educational Success and Social Transformation Through Interactive Groups in Mathematics. European Educational Research Journal, 14(2).

Maiaweng, P. C. D. (2009). Kajian Analisis Terhadap Konsep Pemikiran John Dewey. Jurnal Jaffray, 7(2), 74-86. https://doi.org/10.25278/jj71.v7i2.29

Munazah, Y., Sugianto, \& Nugroho, S. E. (2015). Model Learning Community Berbasis Inkuiri Terbimbing Untuk Meningkatkan Hasil Belajar Siswa Dalam Pelajaran IPA Fisika SMP. Unnes Physics Education Journal, 4(3), 83-93.

Nahar, N. I. (2016). Penerapan Teori Belajar Behavioristik dalam Proses Pembelajaran. Nusantara ( Jurnal IImu Pengetahuan Sosial ), 1, 64-74.

Ni'mah, Z. A. (2017). Urgensi Penelitian Tindakan Kelas Bagi Peningkatan Profesionalitas Guru Antara Cita Dan Fakta. Realita, 15(2), 1-22.

Nidawati. (2013). Belajar dalam Perspektif Psikologi dan Agama. Jurnal Pionir, 1(1), 13-28.

Nurhasanah, S., \& Sobandi, A. (2016). Minat Belajar Sebagai Determinan Hasil Belajar Siswa (Learning Interest Determinant Student Learning Outcomes). Jurnal Pendidikan Manajemen Perkantoran, 1(1), 128135.

Pahliwandari, R. (2016). Penerapan Teori Pembelajaran Kognitif dalam Pembelajaran Pendidikan Jasmani dan Kesehatan. Jurnal Pendidikan Olahraga, 5(2), 154-164.

Purnamawati, I. G. A. (2014). Model Educative Production Function Untuk Meningkatkan Hasil Belajar Akuntansi Perbankan. Jurnal Pendidikan Dan Pengajaran, 47(1), 58-66.

Purnamawati, I. G. A. (2017). Implementation Of Mcgrath's Model On 
Achieving Student Learning

Performance. Journal of Education and Social Sciences, 8(1), 124-130.

Purnamawati, I. G. A., Musmini, L. S., \& Werastuti, D. N. S. (2011). Implementasi Metode Pembelajaran Simulasi Sederhana Bank Mini Untuk Meningkatkan Motivasi Dan Prestasi Belajar Mahasiswa Pada Mata Kuliah Akuntansi Perbankan. Media Komunikasi FPIPS, 10(1). https://doi.org/10.23887/mkfis.v10i1.11 73

Rapi, N. K. (2016). Pengaruh Model Pembelajaran Dan Jenis Penilaian Formatif Terhadap Hasil Belajar IPA Siswa SMPN. Cakrawala Pendidikan, 35(1), 69-79. https://doi.org/10.21831/cp.v1i1.8366

Salazar, D., Agirre-Munoz, Z., Fox, K., \& Lucas, L. N. (2010). On-line Professional Learning Communities: Increasing Teacher Learning and Productivity in Isolated Rural Communities. Systemics, Cybernetics And Informatics, 8(4), 1-7.

Sanusi, U. (2013). Pembelajaran dengan Pendekatan Humanistik (Penelitian pada MTs Negeri Model Cigugur Kuningan). Jurnal Pendidikan Agama Islam-Ta'lim, 11(2), 123-142.

Syafi'i, A., Marfiyanto, T., \& Rodiyah, S. K. (2018). Studi Tentang Prestasi Belajar Siswa Dalam Berbagai Aspek Dan Faktor yang Mempengaruhi. Jurnal Komunikasi Pendidikan, 2(2), 115123. 